Bulletin UASVM Food Science and Technology 70(2)/2013, 153-154

ISSN-L 2344-2344; Print ISSN 2344-2344; Electronic ISSN 2344-5300

\title{
Evaluation of Dairy Sector Safety and Security in Three Hypermarkets (A, B, C) from Transylvania County
}

\section{Romina VLAIC, Sevastița MUSTE, Cristina Anamaria SEMENIUC, Andruţa MUREŞAN, Andrei BORŞA}

Faculty of Food Science and Technology, University of Agricultural Science and Veterinary Medicine, Cluj-Napoca, 3-5, Calea Manăş̧ur Street, 400372 Cluj, Romania rominavlaic@gmail.com

\begin{abstract}
The safety and security of milk and dairy products were monitored in three hypermarkets from Transylvania County by evaluation of several essential key parameters. Results showed variations of quality indicators and this leaded to nomination of each source of interference in order to determine the responsibility of each supermarket.
\end{abstract}

Keywords: hypermarket, quality, milk, safety, storage

Introduction. Maintaining the health of the human body is often related to the health of the food and consumers became more demanding regarding the quality of the food. Controlling, providing and maintaining product quality is increasingly assessed in conjunction with the quality of life (Carminati, 2004). In the market economy of our modern society, food on sale are becoming more diverse, making it dificult for the consumer to determine the quality of the product by comparing it with similar products, so that the choice is not always a real and correct one (Guş, 2005).

Aims. The aim of this study was to monitor the hygienic condition and commercial organization of milk and dairy products sector in three hypermarkets (A, B, C) from Transylvania County.The application of risk analysis and critical control point methodology to the chain of milk and dairy products supply has emphasized on: the food safety control system (FSCS), the compliance with good distribution practices (GDP) and the preparation and application of HACCP plans. The following aspects were taken into account: the condition of food transportation, the reception and storage of milk and dairy products in hypermarket, the organisation of sectors in hypermarket and if the staff hygiene meets the requirements of the food safety program.

Materials and methods. Monitorization and tests verification are essential in food safety management. These observations are very important within the segment of manipulation, transportation and distribution. The quality assurance procedures must be effective. Visual observation is the fastest method; it is used to observe the hygiene of the storage room, the personal protective equipment and the food transport vehicle. Visual observation is an effective method only if it is performed with a certain predetermined frequency and results are systematic recorded. Another important method is the measurement of temperature inside the food transport vehicle and its registration. At milk and dairy products, representative samples are collected for sensory, microbiological and chemical assesment. Sensory analysis is very useful tool to determine the freshness of these products. 


\section{Results and Discussion}

Tab.1

Safety and Security evaluation of the dairy sector

\begin{tabular}{|c|c|c|c|}
\hline $\begin{array}{l}\text { Safety and Security evaluation of } \\
\text { the dairy sector }\end{array}$ & A Hypermarket & B Hypermarket & C Hypermarket \\
\hline $\begin{array}{l}\text { The conditions in which milk and } \\
\text { dairy products were stored }\end{array}$ & $\begin{array}{c}\text { pallets were use for } \\
\text { storage }\end{array}$ & $\begin{array}{l}\text { pallets were used for } \\
\text { storage }\end{array}$ & $\begin{array}{l}\text { pallets were used for } \\
\text { storage }\end{array}$ \\
\hline $\begin{array}{l}\text { The temperature of the } \\
\text { refrigerating room }\end{array}$ & $1{ }^{\circ} \mathrm{C}$ & $3{ }^{\circ} \mathrm{C}$ & $4{ }^{\circ} \mathrm{C}$ \\
\hline $\begin{array}{l}\text { The temperature of the food } \\
\text { cooler }\end{array}$ & $3{ }^{\circ} \mathrm{C}$ & $7{ }^{\circ} \mathrm{C}$ & $9{ }^{\circ} \mathrm{C}$ \\
\hline $\begin{array}{l}\text { The hygiene condition in the } \\
\text { refrigeration room }\end{array}$ & clean & clean & dirty \\
\hline Exceeded shelf-life products & no & no & yes \\
\hline Room for the expired products & yes & yes & $\begin{array}{c}\text { yes, but expired products } \\
\text { were in a basket down the } \\
\text { aisle }\end{array}$ \\
\hline Employees protective equipment & clean & clean & dirty \\
\hline Packaging conditions & yes & yes & No (damaged packaging) \\
\hline $\begin{array}{l}\text { Different price for the same } \\
\text { products at cash register }\end{array}$ & no & Yes ( one case) & Yes ( three cases) \\
\hline Labeling & complete & Incomplete & Incomplete \\
\hline Reception & $\begin{array}{l}\text { quantitative and } \\
\text { qualitative reception }\end{array}$ & $\begin{array}{l}\text { quantitative reception } \\
\text { (only sometimes } \\
\text { qualitative reception ) }\end{array}$ & $\begin{array}{c}\text { quantitative reception } \\
\text { (only sometimes qualitative } \\
\text { reception ) }\end{array}$ \\
\hline
\end{tabular}

Given the above assessment and analysis each hypermarket has cold rooms, but $\mathrm{C}$ hypermarket had no dairy pallets for storage and the products were stored on the floor; however these reviews led to $\mathrm{C}$ hypermarket purchasing pallets and storing the products on these pallets. Maximum allowable storage temperature is $4^{\circ} \mathrm{C}$. In the refrigeration chamber the temperature is the same in all hypermarkets, but in the windows in $\mathrm{B}$ and $\mathrm{C}$ hypermarket it reached 7 to $9^{\circ} \mathrm{C}$; finally, these temperatures were brought to $4^{\circ} \mathrm{C}$ and were more carefully analyzed. In $\mathrm{C}$ hypermarket I found outdated products on the shelves exceeded shelf-life products which were withdrawn from the shelves; however, they were in a basket on the back lane and they should have been in the room for expired items. All expired products were withdrawn from the shelves and they were taken to the room for these types of products, where they were to be scrapped. Staff analyses were ok and the equipments found dirty were changed to clean ones. Shelf prices that did not correspond to those in the checkout were corrected in both hypermarkets; the products which had no expiration date and batch number printed on the packaging were withdrawn from these hypermarkets' shelves. Reception in B and C hypermarkets is to be made every time both quantitatively and qualitatively.

Conclusion. The final results showed that only one hypermarket met the requirements of hygiene.

\section{REFERENCES}

1.Carminati D., (2004). Management of milking hygiene, Theriogenology, (7): 23-56. Napoca.

2.Guş Camelia (2005). Controlul calităţii laptelui şi a produselor lactate, Ed. Risoprint, Cluj- 